\title{
Steroid Sulfatase Deficiency
}

\author{
I.ARRY J. SHAPIRO."W LARRY COUSINS, ARVAN L. FIUHARTY, RICHARD L. STEVIENS, AND \\ HAYATO KIHARA \\ Disision of Medical Ge'netics, Deparme'nt of Pediatrics, and the Departme'nt of Obstetrics and Gynecolegy, Ilarbor \\ General Hospital Campus, UCLA School of Medicine', and the UCLA-Ne'uropsychiatric Institute-Pacific State' \\ Hospital Research Group. Pomona, California, USA
}

\begin{abstract}
Summary
Placental steroid sulfatase deficiency is a genetic disorder only recently reported in the medical literature. 110 st documented cases of placental sulfatase deficiency have been marked by delay in onset of labor, lack of cervical dilatation, and relative refractoriness of oxytocic agents and amniotomy. We have studied the placenta, cultured fibroblasts, and amniotic fluid cells from an affected patient. The activities of estrone sulfatase, pregnenolone sulfatase, dehydroepiandrosterone sulfatase, and arylsulfatase $C$ in the placenta from the patient were severely deficient. Arylsulfatases $\mathbf{A}$ and $\mathbf{B}$ were present at levels within the normal range for this tissue.

Fibroblast dehydroepiandrosterone sulfatase activity was virtually absent in the patient's cells and present at normal levels in individuals with a variety of lysosomal disorders. It would thus appear that the mutation responsible for steroid sulfatase deficiency is genetically and biochemically distinct from those involved in the lysosomal sulfatase deficiency states. The cell culture studies further suggest that the defect is a generalized one which should be detectable in midtrimester of pregnancy and may have phenoty pic consequences in later postnatal life.
\end{abstract}

\section{Speculation}

Further clinical and in vitro studies of patients with this rare inborn error of metabolism should yield information regarding the role of steroid sulfatase in normal metabolism, and in the progress of normal parturition. Once the mechanism by which the level of activity of this enzyme exerts an effect upon labor and delivery is known, appropriate pharmacologic invervention might provide a means for the inhibition of premature labor.

The determination of maternal urinary estriol excretion is a frequently utilized method for monitoring the status of high risk pregnancies (3). Since the production of the large amounts of estriol observed during gestation is dependent on the integrity of the fetal-placental-maternal unit. implications for the well being of a pregnancy may be reflected in alterations of this parameter. Recently, measurement of plasma estriol by radioimmunoassily techniques has supplanted urinary determinations due to the greater sensitivity and ease of sample collection of this newer methodology (s).

Very low third trimester estriol excretion has been noted in four clinical situations: fetal demise in utero, anencephaly, hypoplasia of the fetal adrenal glands, and deficiency of the placental microsomal 3- $\beta$-hydroxysteroid sulfate sulfatase (12).

This latter, genetically determined inborn error of metabolism has recently been the subject of considerable investigation because of the implications of this disorder for the understanding of the mechanisms of control of the onset of labor. We have recently had the opportunity to study tisstes and cultured cells from an affected pregnancy. (Our results provide two important additional pieces of information about this disorder. First, this enymopathy does not affect the activities of lysosomal sulfatase and so these patients should not be expected to develop a sulfolipid or mucopolysaccharide storage disease in later life. Second, this inborn defect is not localized to the placenta, but is generalized to other somatic tissues (at least to cultured fibroblasts) and so maty have elinical consequences not previously appreciated.

\section{CASI: REPOR'I}

$T F$, the proband's mother, a 19-year-old gravida 2, para 1 Caucasian female had her first pregnancy terminated by cesarean section at 42 wechs of gestation because of fetal distress. After spontaneous rupture of the membranes, oxytocin stimulation of labor was attempted in spite of an uneffected. undilated cervix. The procedure was stopped when fetal bradycardia developed. At the time of cesarcan section, a true knot in the cord was found. The male infant has developed normally despite a 1 min Apgar score of 1.

TF"s past medical history, family history, and second pregnancy were uncomplicated. She was referred to the Special Obstetric Clinic at Harbor General Hospital at 3.5 weeks of gestation because of her previous cesarean section and questionable hypohyroidism. Thyroid function studies were normal, but serum estriol was undetectable. Fetal heart tones, fundal growth, and fetal activity were normal. Gray scale ultrasonography revealed a normal biparietal diameter consistent with gestational age. Prodromal labor began at 39 weeks of gestattion, and after mature fetal surfactant levels were confirmed, a repeat lower uterine segment cesarean section was performed. The 3,260-g male newborn had Apgar scores of 7 at 1 min and 9 at 5 min. The placenta weighed $475 \mathrm{~g}$ and was grossly and histologically normal. The infant's nursery course was unremarkable. Physical and neurologic examinations were normal except for first degree hypospadius. Cord cortisol was $17.0 \mu \mathrm{g} / 10(\mathrm{ml}$ and serum electrolytes were normal. There was no evidence of lethargy. vomiting. or diarrheia and the infant has done well since birth.

\section{MATERIALS AND MIEIHODS}

\section{MATIRIALS}

6.7-|3H]Estronc sulfate, ammonium salt (42 (i/mmol), $17-$ $\left.{ }^{3} \mathrm{H}\right]$ pregnenolone sulfate, ammonium salt $(10 \mathrm{Ci} / \mathrm{mmol})$, and [7-3H]dehydroepiandrosterone sulfate, ammonium salt (20) $\mathrm{Ci} / \mathrm{mmol}$ ) were obtained from New England Nuclear. Boston, Mass.; estrone sulfate, dehydroepiandrosterone sulfate, $p$-nitrocatechol sulfate (dipotassium salt), and $p$-nitrophenyl sulfatc (potassium salt) from Sigma Chemical Co., St. Louis, Mo.; and pregnenolone sulfate from Steraloids, Inc., Pawling. N. Y. 4Methylumbelliferyl sulfate was synthesized by the procedure of Sherman and Stanfield (26) and purified according to the method of Rindertinect et al. (25). 


\section{PLASIIA ESTRIOL}

Plasma estriol was measured by a sensitive radioimmunoassay technique (22).

TISSUES

Control and patient placentas were examined in the delivery room, placed inmediately on ice and were processed within 2 hr. Each placenta was extensively washed to free it of adhering blood.and a $10(0-\mathrm{g}$ portion was homogenized in a Waring Blendor with $150 \mathrm{ml}$ cold water. The homogenate was centrifuged at $16,300 \times g$ for $15 \mathrm{~min}$. The supernatant fluid $(130 \mathrm{ml})$ was removed and designated "extract." The precipitated material was suspended in $130 \mathrm{ml}$ water and designated "pellet." Protein estimations of the extract and pellet were made by the procedure of Lowry et al. (18). The remainder of tissue was frozen. Enzyme preparations from the latter gave identical results as the freshly prepared material. The control placenta was obtained from a woman with an uncomplicated pregnancy and normal delivery at term.

\section{CHLL CULTURE STUDIES}

Human fibroblast lines were established from the proband the parents, a single unaffected male sibling, six controls, and from a variety of patients with known inborn errors of metabolism. In addition, amniotic fluid cells from pregnancies of $16-18$ weeks' duration and 34-37 weeks' duration were established as were similar cultures derived from an amniocentesis just before the proband's birth. All cultures were maintained in Eagle's mininum essential medium with $10 \%$ fetal calf serum and were examined at similar times after subculturing at equivalent population densities.

\section{PLACINTAL STIEROID SULFATASE ACTIVITY}

Identical assay procedures were used for estrone sulfatase, pregnemolone sulfatase, and dehydroepiandrosterone sulfatase and were adapted from those of Oakey et al. (23). Tritiated steroid sulfate, $100 \mu \mathrm{l}$ of a $100-\mu \mathrm{M}$ solution $(50(0-1.000 \mathrm{cpm} /$ nmol); $125 \mu \mathrm{l} 25 \mathrm{~m} . \mathrm{M}$ Tris-chloride, pH 8.0 ; and $25 \mu \mathrm{l}$ enzyme were incubated for $30 \mathrm{~min}$ at $37^{\circ}$. The reaction was terminated by placing the reaction tubes on ice for 2 min and then extracting with $0.5 \mathrm{ml}$ benzene. The desulfated product partitioned into the benzene phase, $0.25 \mathrm{ml}$ of which was counted by scintillation spectrophotometry in a toluene-methyl Cellosolve scintillant (17).

\section{PLACINTAL ARYLSUIFATASE C ACTIVITY}

The procedure was an adaptation of the p-nitrophenyl sulfate assay of Dodgson et al. (9) and Milsom et al. (19). Substrate, 50 $\mu 120 \mathrm{mM} p$-nitrophenyl sulfate in $0.25 \mathrm{M}$ Tris-acetate, pll 8.2. and $50 \mu \mathrm{l}$ enzyme were incubated for $1 \mathrm{hr}$ at $37^{\circ}$. The relatively high $\mathrm{pH}$ was used to minimize any possible interference by arylsulfatases $A$ and $B$. The reaction was terminated with the addition of $0.4 \mathrm{ml} \mathrm{N} \mathrm{KOH}$ and the product formed was estimated spectrophotometrically at $420 \mathrm{~nm}$.

\section{PLACENTAL ARYISULFATASES A AND B}

The extract and pellet were examined by a modification of the arylsulfatase $A$ specific assay with $p$-nitrocatechol sulfate of Baum et al. $(2,28)$. The extract was also subjected to chromatography on DEAE-cellulose to separate arylsulfatase $A$ from arylsulfatase $B$ and the fractions were assayed with 4-methylumbelliferyl sulfate as substrate (27).

\section{FIBROBLAST AND ANNIOTIC FLUID CELL ENZYMI: ACTIVITIES}

Cells were harvested by trypsinization and disrupted by freezing and thawing followed by gentle homogenization in a small glass homogenizer. Dehydrocpiandrosterone (DHEAS) sulfatase activity was determined by incubation of up to $100 \mu \mathrm{l}$ homogenate in 0.1 M Tris-HCl buffer, $\mathrm{pH}$ 7.2. Substrate was present at a concentration of $4 \times 10^{-5} \mathrm{M}$ and a specific activity of $15 \mathrm{Ci} / \mathrm{mol}$. The final volume was $250 \mu \mathrm{l}$ and incubation was carried out at $37^{\circ}$ for up to 4 hr. The amount of DHEAS desulfated was determined in the same fashion as for the placental enzymes. Arylsulfatase $A$ and $B$ levels were determined as for the placenta. $\left[{ }^{3 i} S\right]$ Mucopolysaccharide turnover studies were done as described by Cantz e't al. (6).

\section{RESULTS}

\section{PLASMA ESTRIOL}

Plasma estriol was undetectable at 35 and 36 weeks' gestation. At 37 and 38 weeks, the values were $4.8 \mathrm{ng} / \mathrm{ml}$ and $3.5 \mathrm{ng} / \mathrm{ml}$, respectively. The sensitivity of the assay is $2.0 \mathrm{ng} / \mathrm{ml}$. The normal level at 38 wecks' gestation is $18 \mathrm{ng} / \mathrm{ml} \pm 7.5$ ( \pm 2 SD) (22).

\section{PLACENTAL STEROID SULFATASES AND ARYLSULFATASE C}

The activities of estrone sulfatase, pregnenolone sulfatase, dehydropiandrosterone sulfatase, and arylsulfatase $C$ in the extract and pellet of the placenta from the patient were severely deficient (Table 1). Activities were expressed per wet weight of tissue to facilitate comparison of total activities. The protein concentrations of the extract and pellet fractions of the patient were quite similar to those of control, so the same degree of deficiency was noted when activities were expressed on a per $\mathrm{mg}$ protcin basis.

Examination of steroid sulfatase activities of admixtures of extracts of patient and control placentas showed no diminution of control activities (Table 2). This indicated that the observed deficiency of sulfatase activities in the patient's extract was not caused by dissociable inhibitors.

Table 1. Placental sulfatase activities

Fnzyme activitics'

\begin{tabular}{|c|c|c|c|c|c|}
\hline Subjects & Estrone sulfatase & $\begin{array}{l}\text { Pregnenolone sulfa- } \\
\text { tase }\end{array}$ & $\begin{array}{l}\text { Dehydroepiandroster- } \\
\text { one sulfatase }\end{array}$ & Arylsulfatase C & Arylsulfatase $\mathrm{A}$ \\
\hline \multicolumn{6}{|l|}{ Control } \\
\hline Extract & $4+2$ & 9.2 & 500 & 1350 & 1670 \\
\hline Pellet & 550 & $\underline{36.0}$ & $4+2$ & 55 & $22(00)$ \\
\hline Total & 992 & 45.2 & $9+2$ & $\overline{1,405}$ & 3.670 \\
\hline \multicolumn{6}{|l|}{ Paticnt } \\
\hline Extract & 0.5 & $<1.5$ & $<1.5$ & 74 & 2720 \\
\hline Pellet & 20.4 & $\leq 1.5$ & 15.0 & 6 & 2440 \\
\hline Total & 20.9 & $<3.0$ & 16.5 & 80 & 5.160 \\
\hline
\end{tabular}

1 Nanomoles of substrate hydrolyzed per hr per g wet tissue. 
Table 2. Steroid sulfatase activities of mixtures of patient and control extracts

\begin{tabular}{lcc}
\multicolumn{1}{c}{ Enzyme' } & $\begin{array}{c}\text { Estrone sulfa- } \\
\text { tase }\end{array}$ & $\begin{array}{c}\text { Dehydro- } \\
\text { epiandroster- } \\
\text { one sulfatase }\end{array}$ \\
\hline Control $(25 \mu \mathrm{l})+\mathrm{H}_{2} \mathrm{O}(25 \mu \mathrm{l})$ & 219 & 370 \\
Patient $(25 \mu \mathrm{l})+\mathrm{H}_{2} \mathrm{O}(25 \mu \mathrm{l})$ & 3 & 4 \\
Control $(25 \mu \mathrm{l})+$ patient $(25 \mu \mathrm{l})$ & 234 & 382 \\
Blank $\left(\mathrm{H}_{2} \mathrm{O}, 50 \mu \mathrm{l}\right)$ & 7 & 5 \\
\hline
\end{tabular}

${ }^{1}$ Enzyme volume was increased to $50 \mu \mathrm{l}$ and the total reaction volume to $275 \mu \mathrm{l}$ for this experiment.

2 Observed counts per min values.

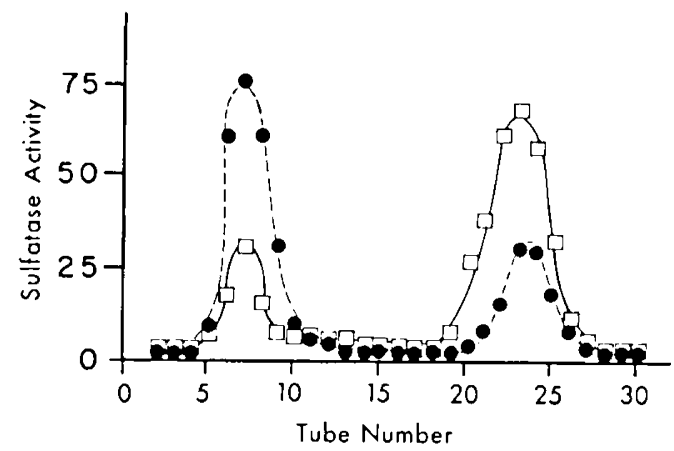

Fig. 1. Chromatographic separation of arylsulfatase $A$ and arylsulfatase $B$ on DEAE-cellulose. Each column $(8 \times 80 \mathrm{~mm}, 25 \mathrm{mM}$ Tris- $\mathrm{HCl}$, pH 7.5) was charged with $3 \mathrm{ml}$ dialyzed extract and developed with $6 \mathrm{ml}$ column buffer, then with $26 \mathrm{ml}$ buffer containing a NaCl gradient (0-().6 1). One-milliliter fractions were collected at $12 \mathrm{ml} / \mathrm{hr}$. Sulfatase activity is given as micromoles of 4 -methylumbelliferyl sulfate hydrolyzed per hr per $1-\mathrm{ml}$ fraction. Control extract $(-\bullet), 21.6 \mathrm{mg}$ protein. Patient extract ( $\square-\square), 18.6 \mathrm{mg}$ protein. Fractions $5-10$ contain arylsulfatase B activity; fractions 20-26 contain arylsulfatase $A$ activity.

\section{PLACENTAL ARYLSULFATASES A AND B}

The arylsulfatase $A$ activity of the subject placenta was actually a bit higher than the control (Table 1). Arylsulfatase A and $B$ in the extract were also evaluated by DEAE-cellulose chromatography (Fig. 1). The level of arylsulfatase B (tubes 510) of the patient placenta was somewhat lower than in the control, whereas the A enzyme (tubes 20-26) was higher. In both cases the enzyme levels were within the normal range for this tissue.

\section{CELL CULTURE STUDIES}

As indicated in Table 3, six normal fibroblast lines had DHEAS-sulfatase activity ranging from 636-2.566 pmol desulfated $/ \mathrm{hr} / \mathrm{mg}$ protein. Values for amniotic fluid cells obtained either at 16-18 weeks' gestation or 34-38 weeks' gestation were somewhat lower. Normal levels of enzyme activity were found in the parents and sibling of the proband and in cells derived from two patients with arylsulfatase $A$ deficiency (metachromatic leukodystrophy) (20), one patient with arylsulfatase B deficiency (Maroteaux-Lamy syndrome) (29), and one patient with iduronate sulfatase deficiency (Hunter syndrome) (1). Low levels were found in I-cell disease fibroblasts and in two patients with multiple sulfatase deficiency (11). In contrast. the activity of DHEAS-sulfatase in fibroblasts and amniotic fluid cells from the proband were below the level of sensitivity of the assay. Fibroblast arylsulfatase $A$ and $B$ activities and $\left[{ }^{35} \mathrm{~S}\right]$ mucopolysaccharide kinetic studies in the patient's fibroblasts were normal (data not shown).

\section{DISCUSSION}

The physiologic occurrence of 3 - $\beta$-hydroxysteroid sulfates has been known for some time. Cholesterol sulfate, $\Delta-5$-pregneno- lone sulfate, 17-hydroxypregnenolone sulfate, and dehydroepiandrosterone sulfate have all been identified in mammalian systems. All can be formed by sulfotransferase-mediated reactions with $3^{\prime}$-phosphoadenosine $5^{\prime}$-phosphosulfate as sulfate donor and enzymatic interversion of these steroids is possible without prior desulfation. It has been speculated that these compounds serve as a storage pool for biologically latent hormones, as transport or excretory forms of various steroids, and as biologic detergents or stabilizers of membranes (4). In spite of the ubiquity of these compounds, none of these functions is known with certainty. The production of a number of $3-\beta$-hydroxysteroid sulfates is increased during pregnancy and it appears that a number of the steps in the transport of these precursors between the mother, placenta, and fetus requires the prior desulfation of some of these compounds. This is accomplished by a placental, neutral pH optimal, microsomal sulfatase (3).

In 1969, France and Liggins (15) reported a case of a genetically determined deficiency of this placental microsomal enzyme. The inability of placental extracts and microsomal pellets to hydrolyze sulfate ester bonds of a number of naturally occurring $\Delta-5-3-\beta$-hydroxysteroid sulfates has since been documented in 14 pregnancies $(5,7,12,15,16,23,24,30)$. The clinical features of pregnancies affected by this enzymopathy have been relatively consistent. All affected fetuses to date have been males, giving rise to speculations of $X$-linked inheritance of this trait. However, as of yet, no genetic pedigree tests of this hypothesis can be made. Mothers carrying affected fetuses have been found to produce very low levels of plasma and urinary estrogens during pregnancy and to have a diminished ability to convert an exogenous load of dehydroepiandrosterone sulfate to estrogen (15). In addition, most pregnancies documented to be affected have failed to result in spontaneous labor and delivery and a relative refractoriness to oxytocic agents and amniotomy has been found. Although uterine contractions can be stimulated, cervical ripening and dilatation often fail to take place. Thus, this enzyme would appear to have some role in the determination of maternal estrogen production and in the control of the onset of labor. No obvious abnormalities have been noted in sulfated metabolites in cord blood from affected infants $(11,12)$. Adrenal stimulation of two children with intravenous corticotrophin resulted in a normal rise in plasma control levels (9) and all patients have exhibited normal grow th and development to date. Thus, if parturition is not allowed to proceed markedly past term, there are no apparent deleterious effects of this enzymopathy.

Fance and Downey (14) have suggested that in their patients with placental sulfatase deficiency, placental arylsulfatases $A$ and $B$ were also diminished in activity, although the specific

Table 3. Dehydrocpiandrosterone (DHEAS)-sulfatase activity in six normal fibroblast lines and sulfatase-deficient pationt

\begin{tabular}{|c|c|c|c|}
\hline Cells (no. of lines) & $\begin{array}{l}\text { DHEAS- } \\
\text { sulfatase, } \\
\mathrm{pmol} / \mathrm{mg} / \mathrm{hr}\end{array}$ & \pm SEM & Range \\
\hline Control fibroblasts (6) & 1.318 & 275 & $6.36-2.566$ \\
\hline 16-18-weck amniotic (3) & 160 & 60 & $59-266$ \\
\hline 34-38-week amniotic (4) & 342 & 41 & $256-4.51$ \\
\hline MLD I & 1,644 & & \\
\hline MLD II & 896 & & \\
\hline Maroteaux-Lamy & 952 & & \\
\hline Hunter & 606 & & \\
\hline I-cell & 274 & & \\
\hline Multiple sulfatase I & 236 & & \\
\hline Multiple sulfatase II & 1.37 & & \\
\hline Proband's father & 1.616 & & \\
\hline Proband's mother & 846 & & \\
\hline Sibling & 778 & & \\
\hline Proband fibroblasts & $<10$ & & \\
\hline $\begin{array}{l}\text { Proband amniotic fluid } \\
\text { cells }\end{array}$ & $<10$ & & \\
\hline
\end{tabular}


assay procedures utilized are not given. Our data demonstrates that there is adequate arylsulfatase $A$ and $B$ activity in the proband's placenta. Furthermore, the cell culture studies show normal levels of arylsulfatase $A$ and $B$ activities in the patient's cultured cells as well as normal mucopolysaccharide metabolism. Also, cells from several patients deficient in known lysosomal sulfatase activities have normal levels of DHEAS-sulfatase activity. It would thus appear that the mutation responsible for steroid sulfatase deficiency is genetically and biochemically distinct from those involved in lysosomal sulfatase deficiency states.

Since steroid sulfatase activity has been described in a number of tissues in experimental animals $(10,21)$, including the pituitary, adrenal, testis, and liver, it is of more than academic interest to know whether the deficiency of activity found in our patient is of a generalized nature or was confined to the placenta. France and Downey (14) have speculated previously that this enzymatic error was limited to the placenta. The finding of very low levels of DHEAS-sulfatase activity in cultured cells from our patient suggests that the phenotypic consequences of this enzymopathy may extend into postnatal life. Further clinical study of affected patients should clarify this point and the role of this enzymatic activity in tissues other than the placenta.

The ability 40 detect this abberration in cultured amniocytes has obvious implications for the prenatal diagnosis of this disorder. Previous attempts at achieving such a diagnosis have utilized intravenous (15) or intraamniotic loading tests with DHEAS (30), or measurement of DHEAS levels in amniotic fluid (5). All of these methods are apparently applicable only during the third trimester; enzymatic assay should be possible considerably carlier.

In summary, it appears that placental sulfatase deficiency is a distinct syndrome with consistent clincial features and enzymologic findings with steroid sulfate substrates. Although relatively rare, many cases of this disorder undoubtedly go unrecognized and will only be ascertained with the application of urinary and plasma estriol determinations. The prolongation of pregnancy seen in this condition is not distinctive, but does have obvious implications for the health of the infant and the mother. Further studies are needed to evaluate the role of steroid sulfatatses in placental function, in the normal progress of labor, and in postnatal adrenal and gonadal function.

\section{REFERIENCES AND NOTIS}

1. Bach, C., Fisenberg. F., Cantz, M.., and Neufeld, L.: The defect in the Hunter syndrome: Deficiency of sulfoiduronate sulfatase. Proce. Natl. Acad. Sci. U. S. A., 70: 2134 (1972).

2. Baum, H., Dodgson, K. S., and Spencer. B.: The assay of arylsulphatases $A$ and $B$ in human urine. (lin. Chim. Acta, $4: 453(1959)$.

3. Beischer, N. A. Bhargava, V. L., Brown, J. B., and Smith, M. A.: The incidence and significance of low oestriol excretion in an obstetric population. J. Obstet. Gynaceol. Brit. Commonw., 75: 1024 (1968).

4. Bleau. G., Bodtey, F. H., Longpre, J., Chapdelaine, A., and Roberts, K. D.: Cholesterol sulfate. 1. Occurrence and possible biological function as an amphipathic lipid in the membrane of the human erythrocyte. Biochim. Biophys. Act:1. 352: 1 (1974).

5. Braunstein, G. D., Ziel, F. H., Allen, A., Van de Velde, R., and Walde, M. E.: Prenatal diagnosis of placental steroid sulfatase deficiency. Amer. J. Obstet. Gynecol., 126: $716(1976)$.

6. Came, M1., Kresse, H., Barton, R, W. and Neufeld, E, F : Corrective factor for inborn errors of mucopolysaccharide metabolism. In: V. Ginsberg: Methods in Enzymology, vol. XXVIII, pp. 884-897 (Academic Press, New York, 1972).

7. Cedard, L., Tchobrousky, C., Guglielmina, R., and Mailhac, M.: Insufficience oestrogenique paradoxale au cours d'une grossesse normale par defaut de sulfatase placentaire. Bull. Fed. Soc. Gynecol. Obstet. Lang. Fr. 23: 16 (1971)
8. Cleary, R. E., and Young, P. C.: Serum unconjugated estriol in normal and abnormal pregnancy. Amer. J. Obstet. Gynecol., 118: 18, (1974).

9. Dodgson, K. S., Spencer, B., and Wynn, C. H.: Studies on sulphatases. 12 The arylsulphatases of human tissues. Biochem. J. 62: 500 (1956).

10. Dolly, J. D., Dodgson, K. S., and Rose, F. A.: Studies on the oestrogen sulphatase and arylsulphatase $\mathrm{C}$ activities of rat liver. Biochem. J., 128: 337 (1972).

11. Eto, Y., Wiesmann, U. N., Carson, J. H., and Herschkowitz. N. N.: Multiple sulfatase deficiencies in cultured skin fibroblasts. Arch. Neurol., 30: 153 (1974).

12. Fliegner, J. R. H., Schindler, I., and Brown, J. B.: Low urinary oestriol excretion during pregnancy associated with placental sulphatase deficiency or congenital adrenal hypoplasiat. J. Obstet. Gynaecol. Brit. Commonw., 79: $810(1972)$.

13. Fluharty, A. L., Stevens, R. L., Sanders, D. L., and Kihara, H.: Arylsulfatase B deficiency in Maroteaux-Lamy syndrome cultured fibroblasts. Biochem. Biophys. Res. Commun., 59: 455 (1974).

14. France, J. T.. and Downey, J. A.: A study of arylsulfatase activity in children born of pregnancies affected with placental sulfatase deficiency. Biochem. Med., 10: 167 (1974).

15. France, J. T., and liggins, G. C.: Placental sulfatase deficiency. J. Clin. Endocrinol. Metab., 29: 138 (1969).

16. France, J. T., Seddon, R. J., and Liggins, G. C.: A study of a pregnancy with low estrogen production due to placental sulfatase deficiency. J. Clin. Endocrinol. Metab.. 36: 1 (1973).

17. Fratantoni, J, C., Hall, C. W., and Neufeld, E. F.: The defect in Hurler's and Hunter's syndromes: faculty degradation of mucopolysaccharide. Proc. Natl. Acad. Sci. U. S. A., O0: 699 (1968).

18. Lowry, O. H.. Rosebrough. N. J., Farr, A. L., and Randall, R. J.: Protein measurement with the Folin phenol reagent. J. Biol. Chem. 19.3: 265 (1951).

19. Milsom. D. W., Rose, F. A., and Dodgson. K. S.: The specific assay of arylsuphatase $C$, a rat liver microsomal marker enzyme. Biochem. J., 128: $331(1972)$

20. Moser, H. W.: Sulfatide lipidesis: metachromatic leukodystrophy. In: J. B. Stanbury, J. B. Wyngarden, and D. S. Fredrickson: The Metabolic Basis of Inherited Discase, Ed. 3, pp. 668-729 (McGraw-Hill Book Co., New York, 1972).

21. Murphy, J. V., IVolfe, J. H., Balzs, E. A., and Moser, H.: A patient with deficiency of arylsulfatases $A, B$ and $C$ and steroid sulfatase, associated with storage of sulfatide, cholesterol sulfate and glycosaminoglycans. In: J. Bernsohn and H. J. Grossman: L.ipid Storage Disease, pp. 67-110 (Academic Press, New York, 1971).

22. Nichols Institute for Endocrinology, Radioimmunoassay Manual, San Pedro, California, 1974

23. Oakey. R. E.. Cawood, M. I... and MacDonald, R. R.: Biochemical and clinicat observations in a pregnancy with placental sulphatase and other enzyme deficiencies. Clin. Endecrinol., 3: 131 (1974).

24. Osathanondh, R., Canick, J., Ryan, K. H., and Tulchinsky, D.: Placental sulfatase deficiency: A case study. J. Clin. Endocrinol. Metab., 43: 208 (1976).

25. Rinderknecht, H., Geokas, M. C., Carmack, C., and Haverback, B.: The determination of arylsulfatases in biological fluids. Clin. Chim. Acta, 29: $481(1970)$

26. Sherman, W. F.. and Stanficld, E. F.: Measurement of the arylsulfatase of Patella iwgata with 4 -methylumbelliferyl sulfate. Biochem. J., 102: 905 $(1967)$.

27. Stevens, R. L.: Minor anionic arylsulfatases in cultured human fibroblasts. Biochim. Biophys. Acta, 370: 249 (1974).

28. Stevens, R. L., Fluharty, A. L... Skokut, M. H., and Kihara, H.: Purification and properties of arylsulfatase $A$ from human urine. J. Biol. Chem.. 250: $2495(1975)$

29. Stumpf. D. A.. Austin. J. H., Crocker. A. C., and L.aFrance, M.: Mucopolysaccharidosis type VI. 1. Sulfatase B deficiency in tissues. Amer. J. Dis. Child., 126: 747 (1973)

30. Tabei, T., and Heinrichs, W. L.: Diagnosis of placental sulfatase deficiency. Amer. J. Obstet. Gynceol.. 124: 409 (1976).

31. The authors wish to thank $R$. T. Miller and $R$. Weiss for their skillful technical assistance, and Mrs. S. Turner for assistance in the preparation of the manuscript.

32. This research was supported by National Institutes of Jealth Training Grant 5 Tol III) (10417-(1).4. Basil () Connor Reseatch (irant 5-6.5 from the National Foundation-March of Dimes, and National Institutes of Health Grants NS1160.5 and 110$)-4612$

33. Requests for reprints should be addressed to: L. J. Shapiro, M.D.. Assistant Professor of Pediatries, Harbor General Hospital. Division of Mectical Genetics, 1000 W. Carson St. Torrance, Calif. 90509 (USA).

34. Received for publication July 22, 1976.

35. Accepted for publication January 6, 1977 